\title{
Benefits of Borrowing from the Federal Reserve when the Discount Rate is Below Market Interest Rates
}

\author{
R. ALTON GILBERT
}

\begin{abstract}
O NE of the privileges of membership in the Federal Reserve System is borrowing at the discount window. Bankers generally rate access to the discount window as one of the most, if not the most, important benefits of Federal Reserve membership. ${ }^{1}$ This paper analyzes the distribution of the benefits of borrowing from the Federal Reserve when the discount rate is below market interest rates, using data from Eighth District member banks. Specifically, the issues considered are whether the distribution of such benefits is concentrated or dispersed among member banks, and whether these benefits accrue primarily to the larger or smaller member banks.
\end{abstract}

\section{THE DISCOUNT FUNCTION: PURPOSES AND ADMINISTRATON}

Lending to member banks is called the discount function of Federal Reserve Banks. ${ }^{2}$ In the early years of its operation, the Federal Reserve changed the amount of reserves in the banking system primarily by discounting commercial paper. From 1917 through 1929, discounts and advances to member banks represented substantial portions of member bank reserves, and in some years were even larger than these reserves. As initially developed, however, the purpose of Federal Reserve discount policy was not only to pro-

\footnotetext{
Peter S. Rose, "Banker Attitudes Toward the Federal Reserve System: Survey Results," Journal of Bank Research (Summer $1977)$, pp. $77-84$

"The tern "discount function" originated from the mechanism through which Federal Reserve Banks extended credit to member banks in the early years of Federal Reserve System operation. Member banks would sell short-term loans that had been made to their commercial customers, endorsing the notes to their Federal Reserve Banks and receiving a fraction of the face amounts of the notes, the fraction reflecting the discount rate. This operation is called discounting a note. Most Fed eral Reserve loans to member banks are now called advances; Federal Reserve Banks lend the amounts requested by member banks, with various types of assets submitted to the Federal Reserve as collateral.
}

vide reserves to the banking system. The policy also attempted to reduce speculation by refusing credit to banks which used funds for such purposes, and to increase the liquidity of the banking system by providing a means for banks to discount their commercial paper. $^{3}$

The objectives of the discount function are now more limited. In most circumstances the Fed attempts to restrict borrowings from the discount window to a small percentage of total member bank reserves by keeping the discount rate close to other short-term interest rates, and by requiring banks to reduce their borrowings if they have exceeded certain general guidelines. Since 1955, when objectives of the discount function were redefined, discounts and advances have averaged only 2.4 percent of member bank reserves, and have accounted for 3 percent or more in only eight years.

The discount function is now viewed as a "safety valve" for the banking system, allowing banks to meet reserve requirements by borrowing to adjust their reserve positions to unusual shocks, such as unanticipated deposit withdrawals or loan demands. Credit through the discount window, generally available only to member banks, also is viewed as a service which enhances the attractiveness of membership. Of course, the Fed still has the important responsibility of lender of last resort in the event of a financial crisis. $^{4}$

The Federal Reserve makes credit available to member banks for various purposes and maturities.

\footnotetext{
${ }^{3}$ Howard H. Hackley, Lending Functions of the Federal Reserve Banks: A History (Washington, D.C.: Board of Governors of the Federal Reserve System, 1973),

4 For comments on how the Federal Reserve System views the discount function, see Reappraisal of the Federal Reserve Discount Mechanism, Volumes $1-3$ (Washington, D.C.: Board of Govemors of the Federal Reserve System, 1971 ).
} 


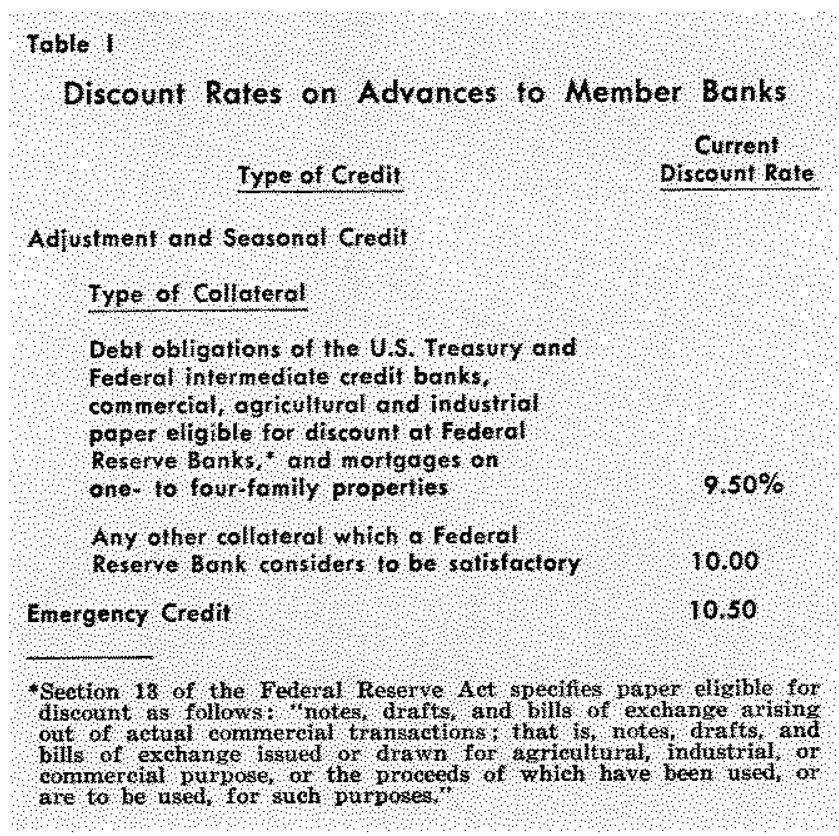

The differences in purpose and maturity are expressed formally in a three-way classification: adjustment credit, seasonal credit, and emergency credit. Guidelines have been developed for extending each category of credit to ensure that member banks borrow only for "appropriate" purposes.

Adjustment credit is available to meet unexpected temporary credit demands caused by sudden deposit withdrawals or unanticipated increases in loan demand. Regulations specify that member banks are not to borrow in order to profit from differences between the discount rate and market interest rates. In particular, banks are not to be net sellers of Federal funds while receiving adjustment credit. ${ }^{5}$

Maturities of adjustment credit loans range from one to thirty days, but can be renewed." Reserve Banks generally grant adjustment credit immediately upon request. 7 However, the longer a reserve adjustment loan is outstanding, the more thoroughly the Reserve Bank lending personnel inquire about the pur-

${ }^{5}$ An exception to this policy applies to member banks that hold deposits of the U.S. Treasury on which they pay interest. Those banks may lend in the Federal funds market amounts equal to the Treasury deposits and still be eligible to receive adjustment credit from the discount window.

${ }^{6}$ Everything You Always Wanted to Know About Borrowing at the Discount Window (But Did Not Ask) (Federal Reserve Bank of Kansas City, January 1978), pamphlet, pp. 2-3.

TAlthongh adjustment credit is granted upon request, prior arrangements between member banks and their Reserve Banks are necessary. A certificate authorizing certain officers of a menber bark to initiate bortowing requests must be on file with the Reserve Bank. Loans to nember banks must be fully poses for borrowing and the reasons why a member bank has not arranged for other sources of finance.

The discount rate on adjustment credit depends upon the type of securities member banks use for collateral. Table I specifies the types of assets which Reserve Banks accept as collateral and the current discount rates which apply to loans with different types of collateral.

Seasonal credit is available to member banks with total deposits of less than $\$ 500$ million which have seasonal patterns in their deposits and loans. (Larger banks generally have a greater ability to cope with seasonal influences.) Seasonal borrowing must be for four weeks or longer, and most banks arrange for seasonal credit in advance. Member banks may be net sellers of Federal funds while borrowing seasonal credit, as long as they do not increase their sales of Federal funds by unusual amounts while borrowing. ${ }^{8}$

The interest rate on seasonal credit is the same as that on adjustment credit. If the discount rate changes while a bank has an outstanding loan, the interest rate on this loan is adjusted from the effective date of the change. Such changes of the discount rate apply to both seasonal and adjustment credit.

Emergency credit may be made available to member or nonmember banks with severe financial diffculties. Banks that receive emergency credit presumably are unable to borrow from sources other than the Federal Reserve, and therefore, are likely to borrow from the Fed for extended periods of time. The discount rate on loans classified as emergency credit is higher than that on adjustment and seasonal credit. ${ }^{9}$ Reserve Banks have some discretion in determining the conditions under which the higher discount rate should be applied. A general guideline Reserve Banks use to classify a loan as emergency

collateralized. Member banks which borrow frequently establish continuing lending agreements with their Reserve Banks. Under these agreements, the banks use certain bonds, which they hold in safekeeping with their Reserve Banks, as collateral for adiustment credit loars. Officers of member banks which have established the authority to borrow and have set up continuing lending agreements can receive adjustment credit by telephoning their Reserve Bank. If an officer calls before a specified time of the day, the amount of the loan is credited to the member bank's reserve account that same day.

8Eventhing You Always Wanted to Know, pp. 3-4. There is no official formula for determining the permissible amourt that a seasonal borrower may lend in the Federal funds market. Reserve Bank lending personnel make that judgment for each seasonal botrower.

${ }^{7}$ In a national emergency, member banks may be exempt from paying the higher discount rate on emergency credit. 
credit is continuous borrowing of more than a bank's required reserves for more than four weeks.

\section{MEASUREG \\ TIE DFNEFIS \\ OF DONTOWING WTOM \\ TIE FEDEMA RESETVE}

Total benefits of access to the discount window are difficult to measure, since these benefits are somewhat subjective. Access to credit in emergency situations is important to many member banks which either seldom borrow or do not plan to borrow from the Fed except in emergency situations. The value of access to credit from the lender of last resort depends upon the bankers' views on the probability of emergency situations developing and the benefits of avoiding such risks.

One benefit which can be easily quantified, however, is the interest expense saved by banks which borrow when the discount rate is below interest rates on altermative sources of funds. As Chart I indicates, borrowings are typically small when the discount rate is above the Federal funds rate. During such periods, member banks rely primarily on other sources of funds in adjusting their reserves to seasonal influences, unanticipated deposit withdrawals, and unexpected loan demands. In contrast, when the Federal funds rate rises above the discount rate, borrowings increase sharply.

In the following analysis, benefits are measured as interest expense saved by borrowing at the discount rate instead of borrowing the same amount at the Federal funds rate. These savings in interest expense relative to reserve balances held at the Federal Reserve are used to analyze variations in the benefits among banks of different size. In addition, the responsiveness of member banks to borrowing when the discount rate is below the Federal funds rate is analyzed, using the interest expense saved per dollar borrowed, which is highest for banks which borrow when the differential between the two rates is greatest.

\section{TOPRONING RY EIGTH DISTRIT MMMER PANG: $10 \% 4$ TO 197}

Since most member banks never borrow - even in periods when the discount rate is substantially below market interest rates - benefits from borrowing at the Fed are concentrated in a small percentage of member banks. ${ }^{19}$ For example, only about one-fourth of Eighth District member banks borrowed in 1974 (Table II), a year in which the discount rate was below the Federal funds rate by an unusually wide margin. In addition, only about 7 percent of member banks borrowed during 1976, when the discount rate was above the Federal funds rate for 344 days.

In each year the percentage of member banks that borrowed was higher for large banks than for small banks. For instance, compare the percentages of banks of various sizes which borrowed in 1974 and 1976. In

\footnotetext{
10The pattern of borrowing at the discomnt window by Eighth District member banks in the years $1974-77$ is similar to that in other periods and other Districts. See Andrew $\vec{F}$, Brimmer, "Menber Bank Borrowing, Portfolio Strategy, and the Managenent of Federal Reserve Discount Policy," Westen Economic Journal (Septenber 1972), pp. 243-97; and A. A. Dill, "Member Batk Botrowing: Process and Experience," Federal Reserve Bank of Atlanta Review (April 1973), pp. 50-54.
} 
Table il

Analysis Of Borrowing By Eighth District Member Banks From The Federal Reserve

(1)

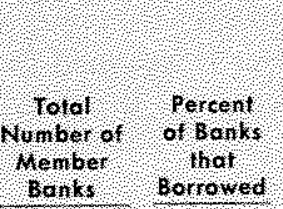

(3)

\begin{tabular}{|c|c|c|c|c|c|c|c|}
\hline $\begin{array}{l}\text { Size Group } \\
\text { Totol assess in } \\
\text { ftions of dollors: }\end{array}$ & $\begin{array}{l}\text { rold } \\
\text { rumber of } \\
\text { Member }\end{array}$ & $\begin{array}{l}\text { persent } \\
\text { ofonls } \\
\text { Bornt }\end{array}$ & 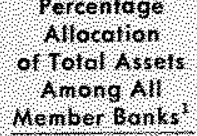 & 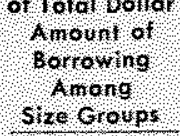 & $\begin{array}{l}\text { Tolol bollor } \\
\text { Benefil lron } \\
\text { Borrowing }\end{array}$ & $\begin{array}{l}\text { rercentoge } \\
\text { Distribution } \\
\text { of Eenefil }\end{array}$ & 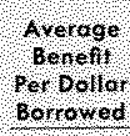 \\
\hline
\end{tabular}

(5)

Totol bollor

Borrowng
161

10741

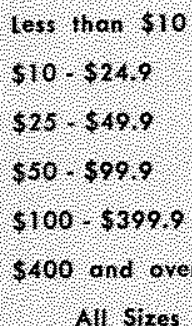

\begin{tabular}{|c|c|}
\hline 97 & $10, \% \%$ \\
\hline 174 & 20.1 \\
\hline 88 & 33.0 \\
\hline 41 & 40.3 \\
\hline 19 & 63.2 \\
\hline 10 & 1000 \\
\hline
\end{tabular}

429

$26.8 \%$

$1000 \%$
$1,9 \%$

10.4

13.4

12.8

14.4

431

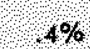

2.3

44

7.0

109

69.0
? $7,755,50$

$42,027,03$

$7,5,79.60$

$117,356.69$

$309,400,68$

$99,2.400 .05$

$\$ 1,542,689,55$

of Eenefi:

Per Dollor

sorrowed.

less, thon $\$ 10$

$\$ 10 \% \$ 24,0$

$\$ 25, \$, 9,9$

$\$ 50, \$ 90 \%$

$\$ 100, \$ 399 \%$

$\$ 400$ and over

All sizes.

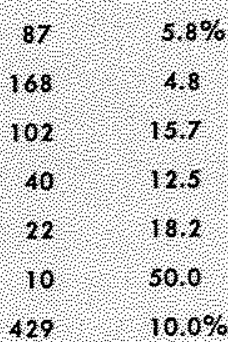

01975

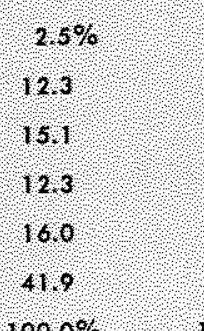

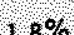

3.1

151

93

10.3

60.4

$1000 \%$

$1000 \%$

\section{$(1976)$}

lew 1 tan 510

$510 \% 524$,

$\$ 25,4499$

$\$ 50, \$ 99.9$

$\$ 100 \$ \$ 3999$

$\$ 400$ ond over

All sizes

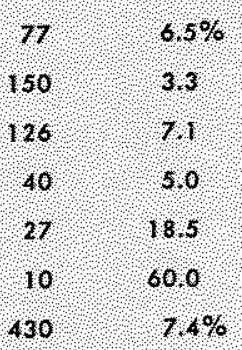

$2.1 \%$
10.3
17.6
11.8
18.5
30.5
$100.0 \%$

\section{$2,6 \%$}

3,3

29.6

7.5

21.6

33.4

$100.0 \%$
$\$$

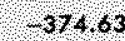

$-446.67$

$-3,345,67$

739.24

$1,725.88$

$4,659.58$

(5) 2,95753

\begin{tabular}{|c|c|}
\hline $8 \%$ & 500344 \\
\hline 27 & 0.0335 \\
\hline 48 & 0.0305 \\
\hline 76 & 0.0305 \\
\hline 201 & 0.0332 \\
\hline 64.3 & 0.0262 \\
\hline
\end{tabular}

$100.0 \%$

\begin{tabular}{|c|c|c|c|c|c|c|c|c|}
\hline ess 1 hon $\$ 10$ & 62 & $8.1 \%$ & $16 \%$ & $2 \%$ & $\$$ & -6703 & $1 \%$ & $\$ 000013$ \\
\hline$\$ 10, \$ 249$ & 143 & 70 & 91 & 14 & & $1,202,27$ & 10 & 0.0037 \\
\hline$\$ 25, \$ 499$ & 123 & 13.0 & 16.3 & 34 & & 4,07007 & 3,3 & 0.0051 \\
\hline$\$ 50, \$ 999$ & 32 & 192 & 137 & 31 & & 3022605 & 3.1 & 00053 \\
\hline$\$ 1004 \$ 3999$ & 31 & 387 & 197 & 308 & & 40,78903 & 32.8 & 0.0056 \\
\hline 5400 ond 0 oer & 10 & 1000 & 39.6 & 612 & & $74,571,81$ & 59.9 & 0.0051 \\
\hline All slzes & 421 & $15.0 \%$ & $1000 \%$ & $100.0 \%$ & 5 & $124,392,20$ & $1000 \%$ & \\
\hline
\end{tabular}

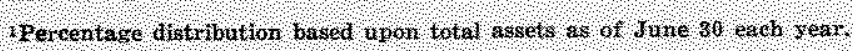


1974 , a year when the average differential between the Federal funds rate and the discount rate was relatively wide, only 10 percent of member banks with total assets less than $\$ 10$ million borrowed from the Fed, whereas 100 percent of banks with total assets over $\$ 400$ million borrowed. In $1976,6.5$ percent of banks in the smallest category borrowed, compared to 60 percent of banks in the largest category. ${ }^{11}$

The percentage distribution of the dollar amount of borrowings among banks of various sizes depends upon whether the discount rate is above or below the Federal funds rate. Member banks with total assets of $\$ 400$ million or more accounted for about 43 percent of the assets (Table II, column 3), and for about 69 percent of total borrowings (column 4) of all Eighth District member banks in 1974. For member banks in the smaller categories, shares of total borrowings were smaller than shares of total assets in 1974 . In contrast, the larger banks accounted for a smaller share of total borrowings ( 33.4 percent) than total assets (39.5 percent) in 1976, when the discount rate was generally above the Federal funds rate. Thus, a greater share of Reserve Bank lending goes to the relatively large banks in periods when the discount rate is below the Federal funds rate.

\section{DISTRIBUTION OF BENEFITS FROM BORROWING AT A RELATIVELY LOW DISCOUNT RATE}

Distribution of the benefits to member banks is analyzed for two years. ${ }^{12}$ The first year is 1974 , in which these benefits were substantial. The differential between the Federal funds rate and the discount rate rose to over 5 percentage points around mid-1974, and averaged about 2.7 percentage points that year-

\footnotetext{
11The restriction that banks not tend in the Federal funds market while receiving adustment credit may be one important reason why proportionately fewer of the small member banks borrow. Most of the small banks are generally net lenders in the Federal funds market. However, as noted above, member banks which have pronounced seasonal pattems in their de posits and loans may obtain seasonal credit while continuing their usual amounts of lending in the Federal funds market.

${ }^{12}$ Benefits to a member bank from borrowing are calculated for each day by dividing the difference between the Federal funds rate and discount wate by 365 (since those interest rates are stated as percent per anmum) and multiplying by the amount borrowed. Benefits are calculated for each year by stmming daily benefits. The discount rate used in calculating benefits from bortowing at the discomt window is the lowest discount rate available to member banks in the Eighth District on each date, which are loans under sections 13 and $13 \mathrm{a}$ of the Federal Reserve Act. During the years covered by this study, 1974-77, no Eighth District member bank was classified as receiving emergency credit.
}

greater than during any of the past ten years. However, this differential was almost as wide during periods in 1969-70 and 1973. Thts, the response of member banks to the availability of substantial benefits from borrowing during 1974 does not represent unique bank behavior, but is assumed to be typical of member banks" response to the relatively large benefits which are occasionally available.

In 1977 , the other year analyzed, the discount rate was above the Federal funds rate for the first four months. However, the Federal funds rate exceeded the discount rate for the rest of the year, with the differential rising to about 75 basis points for a few weeks during the summer and fall. An analysis of the borrowing patterns of individual member banks during 1977 demonstrates their response to a change in the differential between the Federal funds rate and the discount rate from negative to positive.

\section{Distribution of Benefits in 1974}

During 1974, 115 Eighth District member banks received benefits of about $\$ 1.5$ million from borrowing at the discount window (Table II, column 5). These benefits were concentrated among the largest banks (column 6). The ten banks with total assets over $\$ 400$ million had a saving of interest expense equal to almost $\$ 1$ million, about 64 percent of total benefits from borrowing. In contrast, member banks with total assets less than $\$ 100$ million - which comprised 93 percent of all member banks in the Eighth District and which held 43 percent of total assets received only about 16 percent of the benefits.

That the relatively large banks received such a large proportion of the benefits reflects, to some extent, the fact that most of the large banks borrowed in 1974, whereas few of the smaller banks borrowed. A method of analyzing the distribution of benefits among individual member banks is to examine the size of their benefits relative to some measure of bank assets or liabilities. This approach shows whether the small member banks which borrowed in 1974 received benefits, relative to their size, comparable to those received by larger banks. The measure used to adjust for bank size is average reserve balances held at the Fed. Thus, benefits which accrue to member banks from borrowing are calculated as implicit rates of return on average reserve balances held at the Fed.

Benefits from borrowing in 1974 as percentages of reserve balances for various-sized banks are presented 


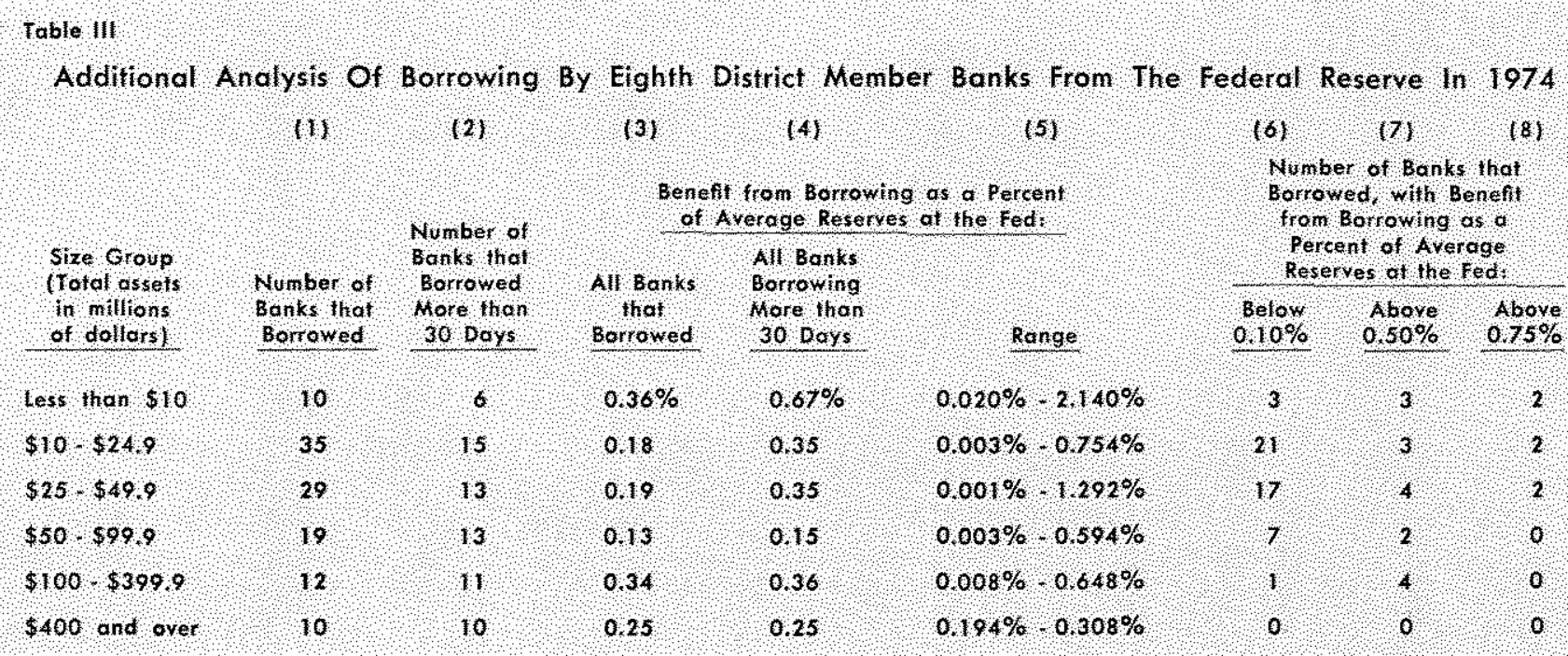

in Table III, column 3. The average rates of return on reserve balances were largest for the banks with total assets up to $\$ 10$ million (0.36 percent), and almost as high for banks with total assets between $\$ 100$ and $\$ 400$ million (0.34 percent).

One factor which limits the usefuness of this rate of return in making comparisons among differentsized banks is that banks borrow for varying lengths of time (Table III, columns 1 and 2 ). To adjust for this influence, benefits as percentages of reserve balances are recalculated, eliminating those banks which borrowed thirty days or less (column 4). This adjustment has a substantial effect on the average implicit return on reserve balances for banks with total assets less than $\$ 10$ million, raising the return from 0.36 percent to 0.67 percent.

Another way to examine the distribution of benefits among individual member banks which borrowed in 1974 is to examine the dispersion of these benefits among banks of similar size. Benefits from borrowing as percentages of average reserve balances at the Fed are rather narrowly dispersed for the ten largest banks, essentially between 0.2 percent and 0.3 percent, with a 0.25 percent return for the group as a whole. This narrow dispersion of benefits reflects the fact that all ten banks borrowed substantial amounts in 1974, and that administrative actions by Federal Reserve Bank lending personnel kept borrowings within the limits which apply to the amounts and duration of borrowing of each member bank. The smaller member banks which borrowed most heavily in 1974 received benefits which, as percentages of their average reserve balances at the Fed, were substantially higher than those for any of the ten largest banks.
One way to determine the importance of these benefits is to compare them to other benefits banks receive from Fed membership. The value of "free" Fed services, other than access to the discount window, average about one-half percent of reserve balances at the Fed for member banks with total assets less than $\$ 50$ million. ${ }^{13}$ Thus, when compared to the implicit rates of return from use of other Fed services, the benefits some banks obtained by borrowing from the Fed in 1974 appear to be substantial. For instance, the six banks with total assets less than $\$ 10$ million that borrowed more than thirty days received benefits that probably exceeded the value of other Fed services they used that year. Thus, several smaller banks obtained major increases in their benefits from Fed membership in 1974 by borrowing from the Fed when the discount rate was substantially below the Federal funds rate.

\section{Distrututhon of Benche in $70 \%$}

The year, 1977, is a good period for examining the relationship between timing of borrowing by member banks and changes in the differential between the Federal funds rate and the discount rate. The discount rate was above the Federal funds rate during the first four months of 1977 , the differential averaging 54 basis points. From May through July, the discount rate was slightly below the Federal funds rate, with an average differential of 14 basis points. The differential rose to over 70 basis points for about four weeks in late summer and fall of that year. From

\footnotetext{
ER. Alton Gilbert, "Utilization of Federal Reserve Bank Serv" ices By Member Banks: Implications for the Costs and Benefits of Membership," this Review (August 1977), pp. 2-15.
} 
August through December, the discount rate was below the Federal funds rate by an average of 56 basis points.

Fifteen percent of all Eighth District member banks borrowed in 1977 (Table II, column 2). The percentage of member banks which borrowed is positively related to bank size. The total dollar amount borrowed was concentrated among the largest banks; those with total assets over $\$ 100$ million accounted for about 59 percent of total assets of all Eighth District member banks, but 92 percent of total borrowing. The total dollar benefit to Eighth District member banks from borrowing in 1977 was about 8 percent of the total for 1974. The total benefit was also concentrated among the largest banks; member banks with total assets over $\$ 100$ million received 92.6 percent of the benefit.

The average benefit per dollar borrowed, shown in the last column of Table II, is used to analyze borrowing patterns in 1977. ${ }^{44}$ Banks which borrowed primarily when the differential between the Federal funds rate and the discount rate was both positive and relatively large had the highest average benefits per dollar borrowed.

Banks in each size group with total assets of $\$ 25$ million or more have approximately the same average benefits per dollar borrowed, averaging about 0.5 cents per dollar borrowed. In contrast, banks with total assets between $\$ 10$ and $\$ 25$ million had average benefits per dollar borrowed of 0.37 cents, and banks with assets up to $\$ 10$ million had negative average benefits of 0.13 cents per dollar borrowed. Thus, member banks with total assets less than $\$ 25$ million appear to be less responsive in timing their borrowing from the Fed to the size of the differential between the Federal funds rate and the discount rate.

This conclusion may be misleading because influences on borrowing patterns other than bank size have not been held constant. An additional influence is the use of the discount window for reserve adjustment on a routine basis. Some member banks borrow infrequently, primarily when the discount rate is below the Federal funds rate, whereas other banks borrow at the discount window several times each year, even during periods when the discount rate is a slight penalty rate. Frequent borrowers apparently borrow

\footnotetext{
14'This meastre is calculated for a bank by dividing the dollar amount of its benefit by average daily borrowings from the Fed, which equals the sim of amounts borrowed on each day divided by 365 .
}

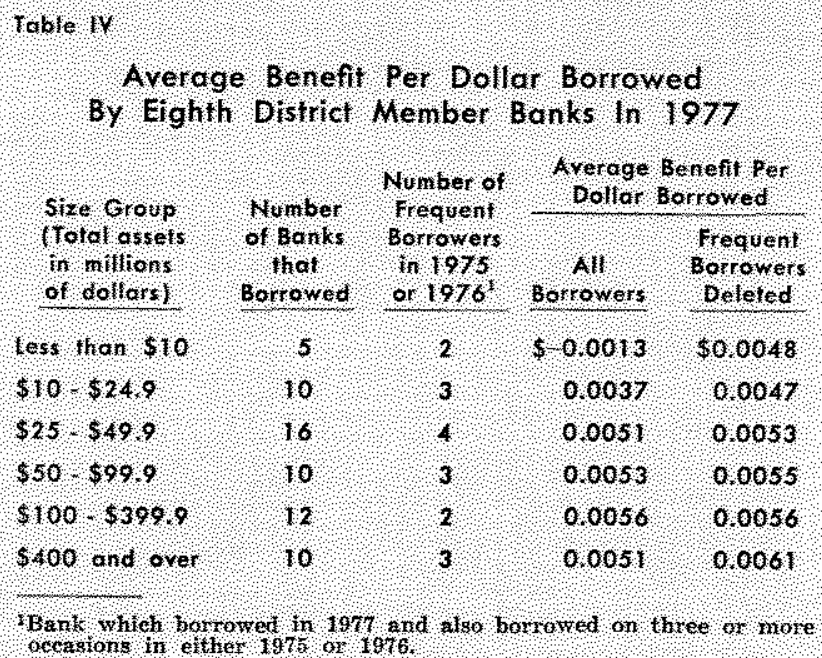

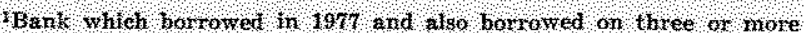
occasions in ather $197 \% 01976$.

from the discount window regularly in making shortterm reserve adjustments to unanticipated events, such as deposit withdrawals or loan demands, and do not change that method of reserve management when the discount rate rises slightly above short-term market interest rates.

In a year such as 1977 , banks which borrow frequently as part of their regular approach to reserve management are likely to have lower average benefits per dollar borrowed than banks which borrow only when the discount rate is below the Federal funds rate by a relatively wide margin. Frequent borrowers are more likely to have borrowed during the first part of the year when the discount rate was above the Federal funds rate, or when the benefits from borrowing were relatively low, since borrowing during those periods may have been dictated by their reserve management policies.

To determine whether such a pattern exists, banks which borrowed in 1977 are divided into two groups: those that borrowed frequently in previous years, and those that borrowed infrequently. Frequent borrowers are those that borrowed on three or more separate occasions in either 1975 or 1976 , when the discount rate was generally above the Federal funds rate. ${ }^{15}$ Average benefits per dollar borrowed in 1977 are recalculated for each group of banks, eliminating the frequent borrowers. As indicated in Table IV, this adjustment increases the average benefit per dollar borrowed for banks in all but one size group: banks with total assets between $\$ 100$ and $\$ 400$ mil-

\footnotetext{
1.5 Specification of banks as frequent botrowers is not in terms of borrowing for three or more days, but borrowing for three or more distinct periods of one or more days each, with interw vening periods of no borrowing.
} 
lion have the same average benefit after eliminating the frequent borrowers. The differences between the average benefit per dollar borrowed for banks with total assets less than $\$ 25$ million and those for most of the larger banks are narrowed by removing the frequent borrowers. Thus, the relatively small member banks which borrow infrequently appear to be about as sensitive as most of the larger banks to borrowing when the differential between the Federal funds rate and the discount rate is relatively wide. ${ }^{16}$

\section{CONCLUSIONS}

One benefit of Federal Reserve membership is the savings in interest expense which accrues to member

\footnotetext{
16The purpose of distinguishing between frequent and infrequent borrowers in this paper is to examine the responsiveness of relatively small banks which borrow infrequently to borrowing when the discount rate is below the Federal funds rate. However, in making the distinction between frequent and infrequent borrowers, additional issues are raised. Why do some member banks borrow frequently? What is the value of the discount window to frequent borrowers? If frequent borrowers became nonmember banks, what sources of short-term credit would they use as substitutes for adjustment credit from the discount window? These issues are beyond the scope of this paper.
}

banks that borrow from the Federal Reserve when the discount rate is below short-term market interest rates. The dollar amounts of such benefits are concentrated among the largest banks since most of the smaller banks never borrow.

Member bank borrowings during 1974 were examined in detail, since that was a year in which the differential between the Federal funds rate and the discount rate was relatively wide. With the savings in interest expense from borrowing at the discount window computed as a percentage of average reserve balances at the Federal Reserve, the relatively small member banks which borrowed heavily during 1974 benefited as much or more than the large banks.

Borrowing patterns in 1977 provide evidence on how member banks respond when the differential between the Federal funds rate and the discount rate changes from negative to positive. Except for member banks which borrow frequently as part of their reserve management strategies, the relatively small member banks which borrow at the discount window appear to be about as sensitive as larger banks to borrowing during periods when the discount rate is below the Federal funds rate. 